\title{
Genetic Constitution of Parthenogenetic Form of Polydrusus inustus (Coleoptera: Curculionidae) - Hints of Hybrid Origin and Recombinations
}

\author{
Łukasz KAJTOCH and Dorota LACHOWSKA-CIERLIK
}

Accepted April 20, 2009

\begin{abstract}
KAJTOCH Ł., LACHOWSKA-CIERLIK D. 2009. Genetic constitution of parthenogenetic form of Polydrusus inustus (Coleoptera: Curculionidae) - hints of hybrid origin and recombinations. Folia biol. (Kraków) 57: 149-156.

Asexual reproduction among insects may arise spontaneously, as a result of infectious agents or hybridization between phylogenetically distinct organisms. Polyploidy, which may be the result of auto- or allopoliploidization (also associated with hybridization), is often connected with parthenogenesis. However, all studied parthenogens of weevils were apomictic, rare meiotic stages have been observed in a few of them what could suggests in their genomes besides the mutational changeability also recombination may occurs. We studied the level of heterozygosity in Internal Transcribed Spacer 2 sequences, and congruence of mitochondrial (cytochrome B) and nuclear genealogies among individuals of parthenogenetic form of Polydrusus inustus. High frequency $(87.0 \%)$ of heterozygotes in ITS2 sequences may indicate a hybrid origin of the parthenogen. It is possible that this parthenogenetic form arose via a hybridization event between phylogenetically distinct lineages of bisexual $P$. inustus, known only from Georgia and Turkey, or between this species and one of the closely relatives from the subgenus Scythodrusus. Although result of partition-homogeneity test did not show significant incongruence of mitochondrial and nuclear genealogies, in the network was detected one loop. Most probable explanations for existence of that loop in parthenogenetic form and for origin of rare homozygotes, which were detected in ITS2 sequences, is gene conversion. It is supported by recently cytogenetic studies indicating rare meiotic stages during the oogenesis of triploids of $P$. inustus.
\end{abstract}

Key words: weevils, hybridization, apomictic, poliploidy, ITS2, mtDNA, gene conversion

Eukasz KAJTOCH, Institute of Systematics and Evolution of Animals, Polish Academy of Sciences, Stawkowska 17, 31-016 Kraków, Poland.

E-mail:kajtoch@isez.pan.krakow.pl

Dorota LACHOWSKA-CIERLIK, Institute of Zoology, Department of Entomology, Jagiellonian

University, R. Ingardena 6, 30-060 Kraków, Poland.

E-mail:dorota.lachowska-cierlik@uj.edu.pl

Asexual reproduction is known in most groups of vertebrates (AVISE et al. 1992) and invertebrates (BELL 1982; NORMARK 2003). It has originated independently many times and takes a variety of forms, but most often it is associated with parthenogenesis. In short, parthenogenesis involves the reproduction of females which produce only daughters without fertilization and pass on only maternal genes. Approximately 900 documented cases of parthenogenesis are known among insects (NORMARK 2003). Such parthenogenetic forms are thought to be short-lived in an evolutionary sense (dead-ends) (WHITE 1970; BELL 1982), but in some cases their genetic diversity is higher than in bisexuals forms (SAURA et al. 1976) and exclusively parthenogenetic taxonomic groups are known as "unisexual scandals" (MAYNARD SMITH 1978). Parthenogenetic reproduction without meiosis and recombination results in offspring (daugh- ters) that are identical clones except for random mutations. Parthenogenesis has originated in at least four ways. Spontaneous parthenogenesis takes place when a mutation occurs in the genes connected to sex, meiosis or hormone levels (SIMON et al. 2002) or sometimes when females fail to mate (SEILER et al. 1961). Infectious agents such as Wolbachia may cause male mortality, cytoplasmic incompatibility or development of haploid eggs into females (STOUTHAMMER et al. 1993; WERREN et al. 1997). However, the most common factor triggering parthenogenesis is probably hybridization. It may arise as a result of hybridization between related species or different (phylogenetically distinct) forms of the same species (HONEYCUTT \& WILKINSON 1989; STENBERG et al. 2003; STENBERG \& LUNDMARK 2004). It is also possible that parthenogenetic genes are transmitted via crossbreeding of a female from a clonal 
lineage of one species and a male from a bisexual species (INNES \& HEBERT 1988; RISPE \& PIERRE 1998). Identification of such hybrids is possible by examining genes from mitochondria (which are only maternally inherited) and nuclear genes (which are a combination of the genes of both parental species). In strictly asexual lineages, phylogenies based on maternally and paternally (or biparentally) inherited markers should correspond perfectly. Polyploidization is often associated with parthenogenesis. The origin of polyploidy in animals can be caused by autopolyploidy (failure of cell division during meiosis or after mitotic doubling, production of unreduced eggs) or allopolyploidy (hybridization between species or different forms of one species) (OTTO \& WHITTON 2000). Asexual forms are often represented by individuals with different levels of ploidy (mostly di-, triand tetraploids). The genealogical interrelations between them are uncertain, i.e. if diploid or triploid parthenogens came into existence first. (LOKKI 1976; SUOMALAINEN et al. 1976; SAURA et al. 1993). Despite of the short life-span of parthenogenetic species (which are mainly also polyploids), they often have high levels of genetic diversity (SUOMALAINEN et al. 1987), heterogeneity in karyotype structure (JUDSON \& NORMARK 1996) and are ecologically successful (LYNCH 1984; SUOMALAINEN et al. 1987). Parthenogenetic (often polyploid) forms have more or less outcompeted their sexual relatives. They often have wider or different geographic distributions. This situation has been described as "geographic parthenogenesis" (VANDEL 1928) and "geographic polyploidy" (STENBERG et al. 2003). Asexual forms are mostly distributed in environments in adverse conditions, e.g. at higher altitudes or latitudes, on islands, in disturbed or marginal habitats (CUELLAR 1994; LYNCH 1984; SUOMALAINEN et al. 1987). They are also considered as first colonizers of new areas, e.g. subsequent to glaciation events (SEILER 1961; KEARNEY 2005; LUNDMARK 2006; LUNDMARK \& SAURA 2006).

Parthenogenetic species or forms have been identified in only a few genera of weevils (SUOMALAINEN et al. 1987; STENBERG et al. 2000, 2003). All clonal weevils that have been examined so far are apomictic, however, SIMON et al. (2003) mentioned the occurrence of automictic species (without citations). SUOMALAINEN (1969) and LOKKI et al. (1976) assumed that parthenogenesis was automictic at the beginning of the evolution of asexual lineages but changed afterwards to apomictic reproduction. This was later questioned by SAURA et al. (1993). However, all studied parthenogenetic forms or species of weevils were apomictic, rare meiotic stages have been postulated during the oogenesis of Otiorhynchus sulcatus
(SEILER 1947) and a few other parthenogens, among others - Polydrusus inustus (LACHOWSKA et al. 2008; LACHOWSKA et al. in preparation). The observation of stages resembling meiosis could confirm hypothesis that the apomictic parthenogenesis evolve through a stage of automixis. The evidence of chromosomes forming figures of rings, crosses and rods - like morphology could suggests that in parthenogenetic genome of weevils besides the mutational changeability also recombination (crossing-over and conversion) may occurs.

In Europe parthenogenetic weevils were studied mainly in Otiorhynchus, Polydrusus and Strophosoma (MIKULSKA 1960; SUOMALAINEN 1969; SUOMALAINEN \& SAURA 1973; LOKKI et al. 1976; SUOMALAINEN et al. 1987; STENBERG et al. 1997, 2000; TOMIUK et al. 1994). Until now nothing is known of the origin of the parthenogenetic form of Polydrusus inustus. This weevil inhabits areas from the Ural and Caucasus Mts in the east to Poland and the eastern slopes of the Carpathian Foothills in the west (KOROTYAEV 1996). Populations of this weevil over most of its range consist of parthenogenetic females and, at least in Poland and Ukraine, they are triploid (LACHOWSKA et al. 2008). Bisexual populations are know only from Georgia and Turkey (KOROTYAEV \& MELESHKO 1995; KOROTYAEV 1996). These weevils live mostly on Rosacea bushes in xerothermic habitats but sometimes are also found on dry wastelands and in strawberry fields.

The aim of this study was to assess a level of heterozygosity in individuals of the parthenogenetic form of $P$. inustus and check congruence between nuclear and mitochondrial sequences. Based on these data conclusions about origin of parthenogenesis and polyploidy and possibility of recombination events were made.

\section{Material and Methods}

Individuals of $P$. inustus were collected from most of their ranges in Poland and western Ukraine (Table 1). Weevils were sampled as adults during several expeditions between 2005-2008. Samples were first preserved in $99 \%$ ethanol and afterwards stored in $22^{\circ} \mathrm{C}$. A total of 5 individuals per population were taken for analyses (except population Hal in which only 2 specimens were collected). DNA was extracted from whole insect bodies using the Dneasy Tissue Kit (Qiagen). Amplification of a fragment of the nuclear internal transcribed spacer 2 (ITS2), and mitochondrial cytochrome b (CytB), was performed using primer pairs ITS3 and ITS4 (WHITE et al. 1990) and CB-J-10933 and CB-N-10920 (SIMON et al. 1994), respectively. 
Table 1

Localization of sample collection sites and distribution of ITS2 "genotypes" and CytB haplotypes in studied weevils. In bold are presented individuals which genotype position in network is uncertain

\begin{tabular}{|c|c|c|c|c|}
\hline $\begin{array}{c}\text { Symbol } \\
\text { of } \\
\text { popula- } \\
\text { tion }\end{array}$ & $\begin{array}{l}\text { Geographic } \\
\text { coordinates }\end{array}$ & $\begin{array}{l}\text { Individ- } \\
\text { ual }\end{array}$ & $\begin{array}{l}\text { ITS2 } \\
\text { geno- } \\
\text { types }\end{array}$ & $\begin{array}{l}\text { CytB } \\
\text { haplo- } \\
\text { types }\end{array}$ \\
\hline \multirow{5}{*}{ Kra } & \multirow{5}{*}{$\begin{array}{l}\text { N } 50^{\circ} 02^{\prime} 32.1^{\prime \prime}, \\
\text { E } 19^{\circ} 52^{\prime} 55.5^{\prime}\end{array}$} & 1 & RR & H1 \\
\hline & & 2 & $\mathrm{RR}$ & H1 \\
\hline & & 3 & $\mathrm{RR}$ & H1 \\
\hline & & 4 & RR & $\mathrm{H} 2$ \\
\hline & & 5 & $\mathrm{RR}$ & $\mathrm{H} 2$ \\
\hline \multirow{5}{*}{ Dal } & \multirow{5}{*}{$\begin{array}{l}\text { N } 50^{\circ} 19^{\prime} 58.6^{\prime \prime} \\
\text { E } 20^{\circ} 12^{\prime} 55.4^{\prime \prime}\end{array}$} & 1 & $\mathrm{RR}$ & $\mathrm{H} 2$ \\
\hline & & 2 & $\mathrm{RR}$ & $\mathrm{H} 3$ \\
\hline & & 3 & $\mathrm{RR}$ & $\mathrm{H} 3$ \\
\hline & & 4 & $\mathrm{RR}$ & $\mathrm{H} 3$ \\
\hline & & 5 & $\mathrm{RR}$ & $\mathrm{H} 3$ \\
\hline \multirow{5}{*}{ Cho } & \multirow{5}{*}{$\begin{array}{l}\text { N } 50^{\circ} 22^{\prime} 30.5^{\prime \prime} \\
\text { E } 20^{\circ} 42^{\prime} 43.9^{\prime \prime}\end{array}$} & 1 & $\mathrm{RR}$ & H1 \\
\hline & & 2 & $\mathrm{RR}$ & $\mathrm{H} 3$ \\
\hline & & 3 & $\mathrm{RR}$ & $\mathrm{H} 3$ \\
\hline & & 4 & $\mathrm{RR}$ & $\mathrm{H} 3$ \\
\hline & & 5 & $\mathrm{RR}$ & $\mathrm{H} 3$ \\
\hline \multirow{5}{*}{ Boc } & \multirow{5}{*}{$\begin{array}{l}\text { N } 51^{\circ} 20^{\prime} 33.1^{\prime \prime} \\
\text { E } 21^{\circ} 58^{\prime} 48.6^{\prime}\end{array}$} & 1 & $\mathrm{RR}$ & H1 \\
\hline & & 2 & $\mathrm{RR}$ & H1 \\
\hline & & 3 & $\mathrm{RR}$ & H1 \\
\hline & & 4 & $\mathrm{RR}$ & H1 \\
\hline & & 5 & $\mathrm{RR}$ & H6 \\
\hline \multirow{5}{*}{ Gro } & \multirow{5}{*}{$\begin{array}{l}\text { N } 50^{\circ} 48^{\prime} 01.6^{\prime \prime} \\
\text { E } 23^{\circ} 57^{\prime} 12.7^{\prime \prime}\end{array}$} & 1 & $\mathrm{RR}$ & H1 \\
\hline & & 2 & $\mathrm{RR}$ & H1 \\
\hline & & 3 & RR & H1 \\
\hline & & 4 & $\mathrm{RR}$ & $\mathrm{H} 4$ \\
\hline & & 5 & $\mathrm{RR}$ & $\mathrm{H} 4$ \\
\hline \multirow{5}{*}{ Kor } & \multirow{5}{*}{$\begin{array}{l}\text { N } 50^{\circ} 24^{\prime} 24.9^{\prime \prime} \\
\text { E } 23^{\circ} 32^{\prime} 25.3^{\prime \prime}\end{array}$} & 1 & GG & $\mathrm{H} 5$ \\
\hline & & 2 & GG & $\mathrm{H} 5$ \\
\hline & & 3 & GG & $\mathrm{H} 5$ \\
\hline & & 4 & GG & $\mathrm{H} 5$ \\
\hline & & 5 & GG & $\mathrm{H} 5$ \\
\hline \multirow{5}{*}{ Mie } & \multirow{5}{*}{$\begin{array}{l}\text { N } 52^{\circ} 19^{\prime} 21.3^{\prime \prime}, \\
\text { E } 23^{\circ} 02^{\prime} 12.2^{\prime \prime}\end{array}$} & 1 & $\mathrm{RR}$ & $\mathrm{H} 5$ \\
\hline & & 2 & $\mathrm{RR}$ & $\mathrm{H} 5$ \\
\hline & & 3 & $\mathrm{RR}$ & $\mathrm{H} 5$ \\
\hline & & 4 & $\mathrm{RR}$ & $\mathrm{H} 5$ \\
\hline & & 5 & $\mathrm{RR}$ & $\mathrm{H} 5$ \\
\hline \multirow{5}{*}{ Roz } & \multirow{5}{*}{$\begin{array}{l}\text { N } 49^{\circ} 43^{\prime} 03.4^{\prime \prime} \\
\text { E } 22^{\circ} 46^{\prime} 49.7^{\prime}\end{array}$} & 1 & $\mathrm{RR}$ & H1 \\
\hline & & 2 & $\mathrm{RR}$ & H1 \\
\hline & & 3 & $\mathrm{RR}$ & H1 \\
\hline & & 4 & $\mathrm{RR}$ & H1 \\
\hline & & 5 & $\mathrm{RR}$ & H1 \\
\hline \multirow{5}{*}{ Jar } & \multirow{5}{*}{$\begin{array}{l}\text { N } 49^{\circ} 58^{\prime} 34.3^{\prime \prime} \\
\text { E } 22^{\circ} 38^{\prime} 14.2^{\prime \prime}\end{array}$} & 1 & $\mathrm{RG}$ & H1 \\
\hline & & 2 & $\mathrm{RG}$ & H1 \\
\hline & & 3 & $\mathrm{RR}$ & H1 \\
\hline & & 4 & $\mathrm{RR}$ & H1 \\
\hline & & 5 & $\mathrm{RR}$ & H1 \\
\hline
\end{tabular}

\begin{tabular}{|c|c|c|c|c|}
\hline $\begin{array}{c}\text { Symbol } \\
\text { of } \\
\text { popula- } \\
\text { tion }\end{array}$ & $\begin{array}{l}\text { Geographic } \\
\text { coordinates }\end{array}$ & $\begin{array}{c}\text { Individ- } \\
\text { ual }\end{array}$ & $\begin{array}{l}\text { ITS2 } \\
\text { geno- } \\
\text { types }\end{array}$ & $\begin{array}{l}\text { CytB } \\
\text { haplo- } \\
\text { types }\end{array}$ \\
\hline \multirow{5}{*}{ Szc } & \multirow{5}{*}{$\begin{array}{l}\text { N } 49^{\circ} 56^{\prime} 28.6^{\prime \prime} \\
\text { E } 20^{\circ} 53^{\prime} 06.9^{\prime \prime}\end{array}$} & 1 & GG & $\mathrm{H} 1$ \\
\hline & & 2 & GG & H1 \\
\hline & & 3 & GG & $\mathrm{H} 1$ \\
\hline & & 4 & $\mathrm{RR}$ & $\mathrm{H} 1$ \\
\hline & & 5 & $\mathrm{RR}$ & $\mathrm{H} 1$ \\
\hline \multirow{5}{*}{ Bis } & \multirow{5}{*}{$\begin{array}{l}\text { N } 49^{\circ} 58^{\prime} 06.5^{\prime \prime} \\
\text { E } 20^{\circ} 06^{\prime} 55.5^{\prime}\end{array}$} & 1 & $\mathrm{RR}$ & $\mathrm{H} 1$ \\
\hline & & 2 & $\mathrm{RR}$ & $\mathrm{H} 1$ \\
\hline & & 3 & $\mathrm{RR}$ & $\mathrm{H} 1$ \\
\hline & & 4 & $\mathrm{RR}$ & $\mathrm{H} 1$ \\
\hline & & 5 & $\mathrm{RR}$ & $\mathrm{H} 1$ \\
\hline \multirow{5}{*}{ Kal } & \multirow{5}{*}{$\begin{array}{l}\text { N } 51^{\circ} 59^{\prime} 14.4^{\prime \prime} \\
\text { E } 21^{\circ} 13^{\prime} 59.3^{\prime \prime}\end{array}$} & 1 & $\mathrm{RR}$ & $\mathrm{H} 1$ \\
\hline & & 2 & $\mathrm{RR}$ & $\mathrm{H} 1$ \\
\hline & & 3 & $\mathrm{RR}$ & $\mathrm{H} 1$ \\
\hline & & 4 & $\mathrm{RR}$ & $\mathrm{H} 1$ \\
\hline & & 5 & $\mathrm{RR}$ & $\mathrm{H} 1$ \\
\hline \multirow{5}{*}{ Mod } & \multirow{5}{*}{$\begin{array}{l}\text { N } 52^{\circ} 25^{\prime} 59.9^{\prime \prime} \\
\text { E } 20^{\circ} 41^{\prime} 25.7^{\prime}\end{array}$} & 1 & $\mathrm{RR}$ & H1 \\
\hline & & 2 & $\mathrm{RR}$ & $\mathrm{H} 1$ \\
\hline & & 3 & $\mathrm{RR}$ & $\mathrm{H} 1$ \\
\hline & & 4 & $\mathrm{RR}$ & $\mathrm{H} 1$ \\
\hline & & 5 & RR & $\mathrm{H} 1$ \\
\hline \multirow{5}{*}{ Wlo } & \multirow{5}{*}{$\begin{array}{l}\text { N } 52^{\circ} 39^{\prime} 44.4^{\prime \prime} \\
\text { E } 19^{\circ} 04^{\prime} 11.6^{\prime \prime}\end{array}$} & 1 & $\mathrm{RR}$ & H5 \\
\hline & & 2 & $\mathrm{RR}$ & H5 \\
\hline & & 3 & $\mathrm{RR}$ & $\mathrm{H} 5$ \\
\hline & & 4 & $\mathrm{RR}$ & H5 \\
\hline & & 5 & $\mathrm{RR}$ & $\mathrm{H} 5$ \\
\hline \multirow{5}{*}{ Gog } & \multirow{5}{*}{$\begin{array}{l}\text { N } 50^{\circ} 29^{\prime} 30.8^{\prime \prime} \\
\text { E } 18^{\circ} 02^{\prime} 59.5^{\prime \prime}\end{array}$} & 1 & AA & $\mathrm{H} 5$ \\
\hline & & 2 & $\mathrm{RR}$ & $\mathrm{H} 5$ \\
\hline & & 3 & RR & $\mathrm{H} 5$ \\
\hline & & 4 & $\mathrm{RR}$ & $\mathrm{H} 5$ \\
\hline & & 5 & RR & $\mathrm{H} 5$ \\
\hline \multirow{5}{*}{ Glo } & \multirow{5}{*}{$\begin{array}{l}\text { N } 51^{\circ} 40^{\prime} 50.6^{\prime \prime} \\
\text { E } 16^{\circ} 04^{\prime} 27.4^{\prime \prime}\end{array}$} & 1 & $\mathrm{RR}$ & $\mathrm{H} 5$ \\
\hline & & 2 & RR & $\mathrm{H} 5$ \\
\hline & & 3 & $\mathrm{RR}$ & $\mathrm{H} 5$ \\
\hline & & 4 & $\mathrm{RR}$ & $\mathrm{H} 5$ \\
\hline & & 5 & $\mathrm{RR}$ & $\mathrm{H} 5$ \\
\hline \multirow{5}{*}{ San } & \multirow{5}{*}{$\begin{array}{l}\text { N } 50^{\circ} 41^{\prime} 26.0^{\prime \prime} \\
\text { E } 21^{\circ} 48^{\prime} 40.5^{\prime}\end{array}$} & 1 & $\mathrm{RR}$ & $\mathrm{H} 1$ \\
\hline & & 2 & RR & $\mathrm{H} 6$ \\
\hline & & 3 & RR & H6 \\
\hline & & 4 & RR & $\mathrm{H} 6$ \\
\hline & & 5 & $\mathrm{RR}$ & $\mathrm{H} 6$ \\
\hline \multirow{5}{*}{ Zlo } & \multirow{5}{*}{$\begin{array}{l}\mathrm{N} 49^{\circ} 39^{\prime} 58.3^{\prime \prime} \\
\text { E } 24^{\circ} 37^{\prime} 00.5^{\prime \prime}\end{array}$} & 1 & GG & $\mathrm{H} 1$ \\
\hline & & 2 & $\mathrm{GG}$ & $\mathrm{H} 1$ \\
\hline & & 3 & GG & H1 \\
\hline & & 4 & $\mathrm{RR}$ & H1 \\
\hline & & 5 & $\mathrm{RR}$ & $\mathrm{H} 1$ \\
\hline \multirow{2}{*}{ Hal } & \multirow{2}{*}{$\begin{array}{l}\text { N } 48^{\circ} 36^{\prime} 19.9^{\prime \prime} \\
\text { E } 24^{\circ} 57^{\prime} 47.2^{\prime \prime}\end{array}$} & 1 & RR & $\mathrm{H} 1$ \\
\hline & & 2 & $\mathrm{RR}$ & H1 \\
\hline
\end{tabular}


The cycling profile for the PCR for both DNA fragments was: $95^{\circ} \mathrm{C}$ for $4 \mathrm{~min}, 35$ cycles of $95^{\circ} \mathrm{C}$ for $30 \mathrm{~s}, 50^{\circ} \mathrm{C}$ for $1 \mathrm{~min}, 72^{\circ} \mathrm{C}$ for $2 \mathrm{~min}$ and a final extension period of $72^{\circ} \mathrm{C}$ for $10 \mathrm{~min}$. PCR fragments after purification (QIAquick Gel Extraction Kit for ITS2; Qiagen's QIAquick PCR Purification Kit for CytB) were sequenced using the BigDye Terminator v.3.1. Cycle Sequencing Kit (Applied Biosystems) and ran on an ABI 3100 Automated Capillary DNA Sequencer. All sequences are deposited in GenBank (Accession nos. FJ430155-FJ430158 and FJ442922- FJ442927). Sequences were checked and aligned using BioEdit v.7.0.5.2 (HALL 1999) and ClustalX (THOMPSON et al. 1997). No indels or stop codons were observed in either of the DNA fragments. In electrochromatograms of ITS2 sequences were found two peaks in two nucleotide positions which were clearly higher than any peaks of background. In these positions nucleotide were ascribed according to IUPAC ambiguity codes. Incongruence between the phylogenetic signals provided by different DNA fragments (mitochondrial and nuclear) was assessed by statistical evaluating the incongruence length difference (ILD) index (MICKEVICH \& FARRIS 1981; FARRIS et al. 1994) using the partition homogeneity test implemented in PAUP* 4.9b10 (SWOFFORD 2002). A Statistical Network Analysis (CRANDALL \& TEMPLETON 1999) was applied in order to verify if distribution of the mitochondrial haplotypes and nuclear "genotypes" are congruent in the studied weevils. Incongruence of these markers was used as proof for hybrid origin (GÓMEZ-ZURITA \& VOGLER 2006; GÓMEZ-ZURITA et al. 2006). Based on mitochondrial haplotypes, a network was constructed using the Statistical Parsimony method (TEMPLETON et al. 1992) and the program TCS 1.21 (CLEMENT et al. 2000). ITS2 "genotypes"were added manually to network of CytB haplotypes, which were co-found in studied individuals.

\section{Results}

The 92 individuals of $P$. inustus from 19 localities yielded 4 ITS2 "genotypes" and 6 CytB haplotypes (Table 1, Fig. 1).

The $528 \mathrm{bp}$ fragments of ITS2 showed only 2 polymorphic sites in positions 249 and 496. Most individuals (84.8\%) were heterozygotes with " $R$ " (G/A) in both positions, 11 individuals $(11.9 \%)$ were homozygotes with guanine $(\mathrm{G})$ in both positions, 1 individual $(1.1 \%)$ was a homozygote with adenine (A) in both positions and 2 individuals $(2.2 \%)$ were heterozygotes with " $\mathrm{R}$ " in position 249 and homozygotes with $\mathrm{G}$ in position 496. As P. inustus is triploid (LACHOWSKA et al. 2008) these heterozygotes have double Gs and single As or double As and single Gs in particular ITS2 sequences. However, peaks of $\mathrm{G}$ were higher than $\mathrm{A}$ peaks in both positions, as evidenced by the sequencing electrochromatograms. The detection of a higher frequency of $\mathrm{G}$ homozygotes in both positions suggests that these heterozygotes are G/G/A. Because it is not clear which combination of nucleotides is correct, we present these "genotypes" as G/A (R). Individuals with the "genotype" RR were found across the entire studied range of the species. Other "genotypes" were limited to specific areas: individuals with "genotype" GG were identified in populations close to the Polish/Ukrainian border (Zlo, Kor) and Carpathian Foothills (Szc). In one population from the Carpathian Foothills (Jar), 2 individuals with "genotype" RG were detected. A single individual with an AA "genotype" was found in a population from Silesia (Gog).

A total of 5 polymorphic sites were detected in $435 \mathrm{bp}$ sequences of CytB. The most common haplotype $\mathrm{H} 1$ was found in 49 individuals $(53.2 \%)$ from most of the studied range of the species, except for the western and northern part of Poland. Haplotype H5 (26 individuals, 28.3\%) was found in the latter localities along the Oder, lower Vistula and Bug valleys (Mie, Wlo, Gog and Glo) and in southeastern Poland (Kor, Roz). Haplotypes H4 (5 individuals, 5.4\%) and H6 (9 individuals, 9.8\%) were identified only in a limited area in the central part of the Vistula valley and Małopolska Upland, respectively. The remaining haplotypes were found in single populations: Kra in the upper Vistula valley (1 individual with haplotype $\mathrm{H} 2$ ), and Gro in the Bug valley (2 individuals with haplotype $\mathrm{H} 3$ ).

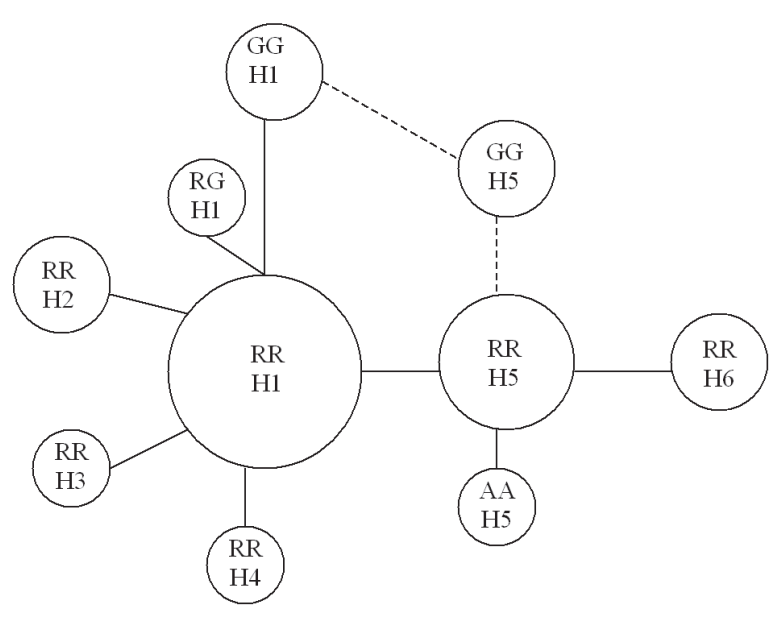

Fig. 1. Network of 6 CytB haplotypes (H1-H6) together with 4 ITS2 "genotypes" (RR, GG, RG and AA) of P. inustus. Sizes of circles correspond to the number of individuals with particular haplotype/"genotype". Broken line represent two possible connection of GG/H5 genotype (loop). 
$44.5 \%$ of individuals had the most common CytB haplotype (H1) and ITS2 "genotype" RR. Only incongruence between these two DNA fragments was found in individuals which had GG "genotype" and $\mathrm{H} 1$ haplotype $(0.5 \%)$ or $\mathrm{H} 5$ haplotype $(0.5 \%)$.

Incongruence of mitochondrial and nuclear sequences was not detected by partition-homogenenity test which was nonsignificant for intergenomic comparison $(\mathrm{P}=1.0)$. Nonsignificant result of that test was caused by the presence of many heterozygotes RR in nuclear sequences which were not parsimony informative.

\section{Discussion}

About $45 \%$ of the individuals share the same and most common "genotype" (RR) and haplotype (H1). This most common "genotype" and haplotype are probably ancestral for the parthenogenetic form of $P$. inustus, at least for populations in central Europe, but also possibly for individuals across the range of this form.

Three sets of chromosomes were present in the studied triploid individuals of $P$. inustus (LACHOWSKA et al. 2008): two probably from one ancestor (double Gs in the polymorphic sites in ITS2 sequences) and one from another (single A nucleotide in polymorphic sites in ITS2 sequences). The origin of parthenogenesis and polyploidy was investigated for diploid and triploid parthenogenetic forms of $P$. mollis in Europe (STROEM 1768) (SUOMALAINEN 1969; LOKKI et al. 1976; TOMIUK et al. 1994), which revealed that parthenogenetic forms were more closely related to each other than to the bisexual form, but it was not certain which asexual form originated first. SUOMALAINEN (1969) and LOKKI et al. (1976) suggested that the triploid asexual form evolved from the diploid asexual, but SUOMALAINEN et al. (1987) and SAURA et al. (1993) argued for a reverse sequence of origin. The heterozygosity of both asexual forms was greater than for the bisexual. SAURA et al. (1993) proposed a cytological mechanism that explained the high degree of heterozygosity observed in asexual forms of this species as defective meiosis leading to diploid gametes and consequently to triploid individuals. A plate disjunction slip may at a later time lead to the origin of the diploid asexual form. However, in subsequent studies it was postulated that the high degree of heterozygosity in $P$. mollis and other asexual forms of weevils may be due to hybridization (SAURA et al. 1993; TOMIUK et al. 1994), as probably occurred during the evolution of the parthenogenetic form of P. inustus.

ITS2 sequences together with internal transcribed spacer 1 (ITS1) are untranslated breaks be- tween 18S, 5.8S and 28S ribosomal DNA genes. These sequences are part of a tandemly repeated unit (family of rDNA genes) and are inherited together. A mutation which appears in one part of this unit is removed or propagated across all repeated units, therefore rDNA sequences (and among them ITS2) should mostly be homozygous. Homogenization of rDNA sequences is caused by molecular drive, gene conversion, unequal crossing-over or transposition (FOGEL \& MORTIMER 1969; HOOD et al. 1975; SMITH 1976; DOVER $1982,1986)$. This is an example of concerted evolution (BROWN et al. 1972; ZIMMER et al. 1980; NEI \& ROONEY 2005). Most of the studied individuals of $P$. inustus were heterozygotes in ITS2 $(87.0 \%)$, indicating that they may have descended from genetically different ancestors. Populations of $P$. inustus consist of parthenogenetic females over most of their range in eastern and central Europe (KOROTYAEV 1996). Bisexual populations of these weevils are known from Georgia and Turkey where they inhabit isolated localities in mountainous regions (KOROTYAEV 1996). They are probably ancestral to the asexual form. The most plausible scenario explaining high frequency of heterozygotes in nuclear DNA in parthenogenetic individuals of $P$. inustus is a hybridization event, which may have occurred between genetically distinct lineages of bisexual P. inustus. A similar scenario for the origin of parthenogenesis was described for $O$. scaber (STENBERG et al. 1997, 2000). Parthenogenetic forms of these weevils arose as a result of hybridization between two distinct bisexual lineages inhabiting isolated localities in the Alps and spread across most of central and northern Europe. The origin of parthenogenetic forms of $P$. inustus may be nevertheless more complicated. Along the western coast of the Caspian Sea and the northeastern coast of Black Sea, $P$. inustus coexists with the closely related species $P$. pilifer (KOROTYAEV \& MELESHKO 1995; KOROTYAEV 1996). The second species also consists of a bisexual form distributed around the eastern and southern coast of the Caspian Sea and a parthenogenetic form in central Asia. In this area, a third species from the subgenus Scythodrusus, $P$. obrieni, (KOROTYAEV et al. 2004) was also recently described. It is probable that the parthenogenetic form of $P$. inustus (and possibly also $P$. pilifer) arose as a result of hybridization between different ancestral species. It is also possible that parthenogenetic genes are transmitted via crossbreeding of a female from the clonal lineage of another species and a male from $P$. inustus, as detected in many other invertebrates (INNES \& HEBERT 1988; RISPE \& PIERRE 1998). Indeed, such an origin of parthenogenesis is thought to be the major route to polyploidy (SIMON et al. 2003). In the parthenogenetic form of $P$. inustus, triploidy 


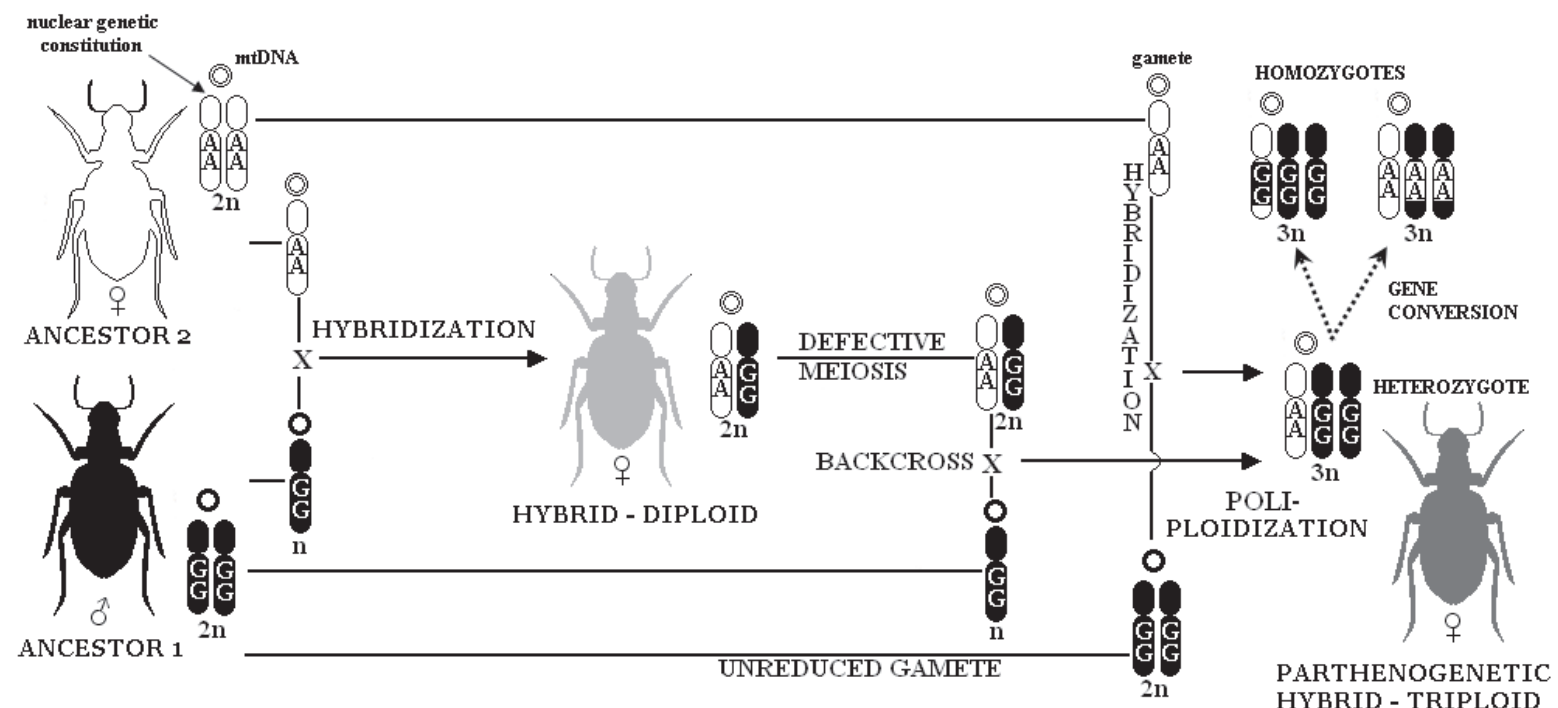

Fig. 2. Possibly scenarios of origin of parthenogenesis and ploidy in P. inustus via hybridization and polyploidization events (adapted from SAURA et al. 1993) and rare homozygotes via conversion. A and G represent nucleotides in two polymorphic sites of the ITS2 sequences. For details see text.

possibly arose as a result of cross-breeding between a diploid hybrid form with one of their ancestral taxon (phylogenetically distinct lineage or species) or cross-breeding between ancestral taxons which one had produced unreduced gamete (Fig. 2). The possible presumed deduction of the hybrid origin of the parthenogenetic form of $P$. inustus needs further investigation through a comparison of mitochondrial and nuclear sequences from all bisexual and parthenogenetic forms of $P$. inustus and its Scythodrusus relatives from their entire ranges.

In asexually breeding animals strict congruence between nuclear and mitochondrial genes should be observed because all parts of the genome are inherited together (as one locus; SIMON et al. 2003). The incongruence of mitochondrial and nuclear sequences was not detected but a few individuals with "genotypes" GG and CytB haplotypes H5 which may be connected in two ways in network (create a loop) - situation which is rather improbable in strict apomictic form. They may originate as a result of sporadic sexual breeding, convergent mutations in nuclear or mitochondrial sequences, gene conversion and crossing-over (SIMON et al. 2003). As males of $P$. inustus has never been detected outside Georgia and Turkey (KOROTYAEV 1996; MAZUR 1994) such a explanation is not convinced. Haplotypes $\mathrm{H} 1$ and $\mathrm{H} 5$ differ only by one mutation so it cannot be excluded that such a mutation occur twice: in lineage $\mathrm{RR} / \mathrm{H} 1-\mathrm{RR} / \mathrm{H} 5$ and in lineage RR/H1 - GG/H1 - GG/H5. However it is also probable that GG "genotypes" originate twice in lineages: $\mathrm{RR} / \mathrm{H} 1-\mathrm{RR} / \mathrm{H} 5-\mathrm{GG} / \mathrm{H} 5$ and RR/H1
- GG/H1. Identification of homozygotes in both (GG and AA) or one (RG) of the polymorphic sites in ITS2 sequences would be difficult to explain in terms of mutation. This especially applies to individuals homozygous in both nucleotide positions (249 and 496 in studied sequences), the more so because no other mutations were detected in other parts of the ITS2 sequences. Origin of homozygotes may be explained as a result of gene conversion - the replacement of one DNA fragment in one chromosome by a homologous sequence from another chromosome (i.e. loose of A allele and addition of $\mathrm{G}$ allele which gives GG homozygote) (Fig. 2). Conversion, which is one way of recombination, has been considered as improbable in apomictic animals, however, somatic crossing-over (endomeiosis) were offered to account for sudden bursts of variation in parthenogenetic aphids and cladoceran populations (BACCI et al. 1961; COGNETTI 1961). According to COGNETTI (1961) pairing of chromosomes leads to chiasma formation and gene recombination. These conclusions were nevertheless not concord with studies of SUOMALAINEN (1950) and BLACKMAN (1978) which were against possibility of endomeiotic recombination events. Recently intensive cytogenetic studies on parhenogenetic weevils (among others $-P$. inustus) reviewed rare occurence of atypical course of apomictic oogenesis with stages similar to meiosis, in which chromosomes form bivalents and multivalent clusters (LACHOWSKA et al. 2008; LACHOWSKA et al. in preparation). These associations of chromosomes probably represents the remnants of meiosis, although it is uncertain if 
these events have something to do with recombination. Detection of rare homozygous individuals among prevailing heterozygous $P$. inustus support the hypothesis that recombination (gene conversion) might occasionally happened but further research is needed to confirm it.

\section{Acknowledgements}

The authors thank Dr. hab. Mieczysław MAZUR for kindly providing part of material. This work was partly supported by a grant (N304 085 31/3279) from the Polish Ministry of Higher Education and Science.

\section{References}

Avise J. C., Quattro J. M., VRiJenhoek R. C. 1992. Molecular clones with organismal clones: mitochondrial DNA phylogenies and the evolutionary histories of unisexual vertebrates. Evol. Biol. 26: 225-246.

BACCI G., COGNeTti G., VACCARI A. M. 1961. Endomeiosis and sex determination in Daphnia pulex. Experientia 17: 505-506.

BELL G. 1982. The Masterpiece of Nature. Croom Helm, London.

BLACKMAN R. L. 1978. Early development of the parthenogenetic eggs in three species of aphids (Homoptera: Aphididae). Int. J. Insect Morphol. Embryol. 7: 33-44.

BRown D. D., WENSINK P. C., JORDAN E. 1972. Xenopus laevis and Xenopus mulleri: the evolution of tandem genes. Mol. Biol. 63: 57-73.

Clement M., Posada D., CRandall K. A. 2000. TCS: a computer program to estimate gene genealogies. Mol. Ecol. 9: 1657-1659.

COGNETTI G. 1961. Endomeisosis in parthenogenetic lines of aphids. Experientia 17: 168

Crandall K. A., Templeton A. R. 1999. Statistical approaches to detecting recombination. (In: The Evolution of HIV. CRandall K. A. ed. The Johns Hopkins University Press, Baltimore): 153-176.

CUELLAR O. 1994. Biogeography of parthenogenetic animals. Biogeographica 70: 1-13.

Cunningham C. W. 1997. Can three incongruence tests predict when data should be combined? Mol. Biol. Evol. 14 733-740.

DOVER G. 1982. Molecular drive: a cohesive mode of species evolution. Nature 299: 111-117.

DOVER G. 1986. Molecular drive in multigene families: how biological novelties arise, spread and are assimilated. Trends Genet. 2: 159-165.

FArris J. S., KÄLlers.Jo M., Kluge A. G., Bult C. 1994. Testing significance of incongruence. Cladistics 10: 315-319.

Fogel S., MORTIMER R. K. 1969. Information transfer in meiotic gene conversion. Proc. Natl. Acad. Sci. 62: 96-103.

GómeZ-Zurita J., VogLer A. P. 2006. Testing introgressive hybridization hypotheses using statistical network analysis of nuclear and cytoplasmic haplotypes in the leaf beetle $T i$ marcha goettingensis species complex. J. Mol. Evol. 62: 421-433.

GómeZ-Zurita J., FunK D. J., Vogler A. P. 2006. The evolution of unisexuality in Calligrapha leaf beetles: Molecular and ecological insights on multiple origins via interspecific hybridization. Evolution 60: 328-347.
HALl T. A. 1999. BioEdit: a user-friendly biological sequence alignment editor and analysis program for Windows 95/98/NT. Nucleic Acids Symp. Ser. London 41: 95-98.

HONEYCUTT R. L., WILKINSON P. 1989. Electrophoretic variation in the parthenogenetic grasshopper Warramaba virgo and its sexual relatives. Evolution 43: 1027-1044.

Hood L., CAmpBell J. H., Elgin S. C. 1975. The organization, expression, and evolution of antibody genes and other multigene families. Annu. Rev. Genet. 9: 305-353.

INNES D. J., HEBERT P. D. N. 1988. The origin and genetic basis of obligate parthenogenesis in Daphnia pulex. Evolution 42: 1024-1035.

JUDSON P. O., NORMARK B. B. 1996. Ancient asexual scandals. Trends in Ecology and Evolution 11: 41-46.

KEARNEY M. 2005. Hybridization, glaciation and geographical parthenogenesis. Trends. Ecol. Evol. 20: 495-502.

KOROTYAEV B. A. 1996. Use of data on distribution of the bisexual and parthenogenetic forms of weevils for faunogenetic reconstructions (Coleoptera, Curculionidae). Verhandlungen des 14. Intern. Symp. Entomofaunistik in Mitteleuropa, SIEEC Munchen. (04.-09.09.1994): 264-271.

Korotyaev B. A., MeleshKo J. E. 1995. The peculiarities of the distribution of parthenogenetic weevils on example of Polydrusus inustus Germ. and P. pilifer Hochh. (Coleoptera, Curculionidae). Fauna and taxonomy: Proc. Zool. Mus. Baylor Univ., Minsk 1: 213-227. (In Russian).

Korotyaev B. A., ISMailov M. Sh., MeleshKo J. E. 2004. A New Species of the Weevil Genus Polydrusus Germ.(Coleoptera, Curculionidae) from Inner Daghestan.

http://www.maik.ru/abstract/enteng/3/enteng0390_abstract.pdf

LACHOWSKA D., RoŻEK M., HolECOVÁ M. 2008. New data on the cytology of parthenogenetic weevils (Coleoptera, Curculionidae). Genetica 134: 235-242.

LOKKI J. 1976. Genetic polymorphism and evolution in parthenogenetic animals. VIII. Heterozygosity in relation to polyploidy. Hereditas 83: 65-72.

LOKKi J., SAURA A., LANKINEN P., SuOMalainEn E. 1976. Genetic polymorphism and evolution in parthenogenetic animals. VI. Diploid and tetraploid Polydrosus mollis (Coleoptera: Curculionidae). Hereditas 82: 209-216.

LUNDMARK M. 2006. Polyploidization, hybridization and geographical parthenogenesis. Trends Ecol. Evol. 21: 9.

LundMARK M., SAURA A. 2006. Asexuality alone does not explain the success of clonal forms in insects with geographical parthenogenesis. Hereditas 143: 24-33.

LYNCH M. 1984. Destabilizing hybridization, generalpurpose genotypes and geographical parthenogenesis. Q. Rev. Biol. 59: 257-290.

MAYNARD SMITH J. 1978. The evolution of sex. Cambridge University Press, Cambridge.

MAZUR M. 1994. Distribution and migration of Polydrusus inustus Germar, 1824 (Coleoptera: Curculionidae). Pol. Pis. Entomol. 63: 113-132. (In Polish).

MicKEVICH M. F., FARRIS J. S. 1981. The implications of congruence in Menidia. Syst. Zool. 30: 351-370.

MiKULSKA I. 1960. New data on the cytology of the parthenogenetic weevils of the genus Otiorrhynchus Germ. (Curculionidae, Coleoptera) from Poland. Cytologia 25: 322-333.

NEI M., Rooney A. P. 2005. Concerted and birth- and death evolution of multigene families. Ann. Rev. Genet. 39: 121-152.

NORMARK B. B. 2003. The evolution of alternative genetic systems in insects. Annu. Rev. Entomol. 48: 397-423.

OTTO S. P., WhitTON J. 2000. Polyploid incidence and evolution. Ann. Rev. Genet. 34: 401-437.

RisPe C., PIERRE J. S. 1998. Coexistence between cyclical parthenogens, obligate parthenogens, and intermediates in a fluctuating environment. J. Theor. Biol. 195: 97-110.

SAURA A., LOKKI J., LANKINEN P., SUOMALAINEN E. 1976. Genetic polymorphism and evolution in parthenogenetic 
animals. III. Tetraploid Otiorrhynchus scaber (Coleoptera: Curculionidae). Hereditas 82: 79-99.

SAURA A., LOKKI J., SUOMALAINEN E. 1993. Origin of polyploidy in parthenogenetic weevils. J. Theor. Biol. 163: 449-456.

SEILER J. 1947. Die Zytologie eines parthenogenetischen Rüsselkäfers, Otiorrhynchus sulcatus. F. Chromosoma 3: 88-109.

SEILER J. 1961. Untersuchungen über die Entstehung der Parthenogenese bei Solenobia triquetrella F. R. (Lepidoptera, Psychidae) III. Die geographische Verbreitung der drei Rassen von Solenobia triquetrella (bisexuell, diploid und tetraploid parthenogenetisch) in der Schweiz und in angrenzenden Ländern und die Beziehungen zur Eiszeit. Bemerkungen über die Entstehung der Parthenogenese. Z. Vererbungslehre 92: 261-316.

Simon C., Frati F., Bechenbach A., Crespi B., LiU H., FLOCK P. 1994. Evolution, weighting, and phylogenetic utility of mitochondrial gene sequence and compilation of conserved polymerase chain reaction primers. Ann. Entomol. Soc. Am. 87: 651-701.

SimON J. C., RisPE C., SUNNUCKS P. 2002. Ecology and evolution of sex in aphids. Trends Ecol. Evol. 17: 34-39.

Simon J. C., Delmotte F., Rispe C., CRease T. 2003. Phylogenetic relationships between parthenogens and their sexual relatives: the possible routes to parthenogenesis in animals. Biol. J. Linnean Soc. 79: 151-163.

SMITH G. P. 1976. Evolution of repeated DNA sequences by unequal crossover. Science 191: 428-535.

StenBerg P., Terhivuo J., LOKKi J., SAURA A. 2000. Clone diversity in the polyploid weevil Otiorhynchus scaber. Hereditas 132: 137-142.

STENBERG P., LUNDMARK M. 2004. Distribution, mechanisms and evolutionary significance of clonality and polyploidy in weevils. Agric. For. Entomol. 6: 1-8.

StenBerg P., Terhivuo J., LOKKI J., SAURA A. 1997. Clone diversity of tetraploid Otiorhynchus scaber in northern Europe. Hereditas 126: 169-172.

StenBerg P., Lundmark M., KnUtelski S., SAURA A. 2003. Evolution of clonality and polyploidy in a weevil system. Mol. Biol. Evol. 20: 1626-1632.

STOUTHAMMER R., BREEUWER J. A., LUCK R. F., WERREN J. H. 1993. Molecular identification of microorganisms associated with parthenogenesis. Nature 361: 66-68.

SuOMAlainen E. 1950. Parthenogenesis in animals. Adv. Genet. 3: 193-253.
SUOMALAinEn A. 1969. On the sex chromosome trivalent in some Lepidoptera females. Chromosoma 28: 298-308.

SuOMALAINEN A., SAURA A. 1973. Genetic polymorphism and evolution in parthenogenetic animals. I. Polyploid Curculionidae. Genetics 74: 489-508.

SuOMALAinen E., SAURA A., LOKKI J. 1976. Evolution of parthenogenetic insects. Evol. Biol. 9: 209-257.

SuOMALAinen E., SAURA A., LOKKI J. 1987. Cytology and Evolution in Parthenogenesis. CRC Press, Boca Raton.

SwOFFORD D. L. 2002. PAUP*. Phylogenetic Analysis Using Parsimony (*and other methods). Ver. 4. Sinauer Associates, Sunderland, MA.

Templeton A. R., Crandall K. A., Sing C. F. 1992. A cladistic analysis of phenotypic associations with haplotypes inferred from restriction endonuclease mapping and DNA sequence data. III. Cladogram estimation. Genetics 132: 619-633.

Thompson J. D., Gibson T. J., Plewniak F., Jeanmougin F., Higgins D. G. 1997. The ClustalX windows interface: flexible strategies for multiple sequence alignment aided by quality analysis tools. Nucleic Acids Res. 24: 4876-4882.

TOMIUK J., LOESCHCKE V. 1994. On the origin of polyploid parthenogenetic races in the weevil Polydrusus mollis (Coleoptera: Curculionidae). J. Theor. Biol. 167: 89-92.

VANDEL A. 1928. La parthénogenčse géographique. Contribution ŕlletude biologique et cytologique de la parthénogenčse naturelle. Bull. biol. Fr. Bel. 62: 164-281.

WERREN J. H. 1997. Biology of Wolbachia. Annu. Rev. Entomol. 42: 587-609.

WhiTE M. J. D. 1970. Heterozygosity and genetic polymorphism in parthenogenetic animals. (In: Essays in Evolution and Genetics in Honor of Theodosius Dobzhansky. HECHT M. K. and STEERE W. C. eds New York: North Holland): 237-262.

White T. J., BRUNS T., LEE S., TAYLOR J. 1990. Amplification and direct sequencing of fungal ribosomal RNA genes for phylogenetics. (In: PCR Protocols: A Guide to Methods and Applications. Innis M. A., Gelfand D. H., Shinsky J. J., White T. J. eds. Academic Press, San Diego): 315-322.

Zimmer E. A, Martin S. L., BeVERly S. M., KAN Y. W., WILSON A. C. 1980. Rapid duplication and loss of genes coding for the chains of hemoglobin. Proc. Natl. Acad. Sci. USA 77: 2158-2162. 